\title{
Severe acute respiratory infection in children in a densely populated urban slum in Kenya, 2007-2011
}

\author{
Robert F Breiman ${ }^{1,2,5^{*}}$, Leonard Cosmas ${ }^{1}$, M Kariuki Njenga ${ }^{1,2,4}$, John Williamson ${ }^{1,2}$, Joshua A Mott ${ }^{1}$, Mark A Katz ${ }^{1,2}$, \\ Dean D Erdman ${ }^{3}$, Eileen Schneider ${ }^{3}$, M Steven Oberste ${ }^{3}$, John C Neatherlin ${ }^{1,2}$, Henry Njuguna ${ }^{1,2}$, Daniel M Ondari ${ }^{4}$, \\ Kennedy Odero ${ }^{4}$, George O Okoth ${ }^{4}$, Beatrice Olack ${ }^{4}$, Newton Wamola ${ }^{4}$, Joel M Montgomery ${ }^{1,2}$, Barry S Fields $s^{1,2}$ \\ and Daniel R Feikin ${ }^{1,2,3}$
}

\begin{abstract}
Background: Reducing acute respiratory infection burden in children in Africa remains a major priority and challenge. We analyzed data from population-based infectious disease surveillance for severe acute respiratory illness (SARI) among children $<5$ years of age in Kibera, a densely populated urban slum in Nairobi, Kenya.

Methods: Surveillance was conducted among a monthly mean of 5,874 (range $=5,778-6,411$ ) children $<5$ years old in two contiguous villages in Kibera. Participants had free access to the study clinic and their health events and utilization were noted during biweekly home visits. Patients meeting criteria for SARI (WHO-defined severe or very severe pneumonia, or oxygen saturation <90\%) from March 1, 2007-February 28, 2011 had blood cultures processed for bacteria, and naso- and oro- pharyngeal swabs collected for quantitative real-time reverse transcription polymerase chain reaction testing for influenza viruses, parainfluenza viruses (PIV), respiratory syncytial virus (RSV), adenovirus, and human metapneumovirus (hMPV). Swabs collected during January 1, 2009 - February 28, 2010 were also tested for rhinoviruses, enterovirus, parechovirus, Mycoplasma pneumoniae, and Legionella species. Swabs were collected for simultaneous testing from a selected group of control-children visiting the clinic without recent respiratory or diarrheal illnesses.

Results: SARI overall incidence was 12.4 cases/100 person-years of observation (PYO) and 30.4 cases/100 PYO in infants. When comparing detection frequency in swabs from 815 SARI cases and 115 healthy controls, only RSV and influenza A virus were significantly more frequently detected in cases, although similar trends neared statistical significance for PIV, adenovirus and hMPV. The incidence for RSV was 2.8 cases/100 PYO and for influenza A was 1.0 cases/100 PYO. When considering all PIV, the rate was 1.1 case/100 PYO and the rate per 100 PYO for SARI-associated disease was 1.5 for adenovirus and 0.9 for hMPV. RSV and influenza A and B viruses were estimated to account for $16.2 \%$ and $6.7 \%$ of SARI cases, respectively; when taken together, PIV, adenovirus, and hMPV may account for $>20 \%$ additional cases.
\end{abstract}

Conclusions: Influenza viruses and RSV (and possibly PIV, hMPV and adenoviruses) are important pathogens to consider when developing technologies and formulating strategies to treat and prevent SARI in children.

\footnotetext{
* Correspondence: rfbreiman@emory.edu

${ }^{1}$ Global Disease Detection Division and Influenza Division of the United

States Centers for Disease Control and Prevention (CDC Kenya office),

Nairobi, Kenya

${ }^{2}$ Global Disease Detection Branch, Division of Global Health Protection,

Center for Global Health, Centers for Disease Control and Prevention, Atlanta,

GA, USA

Full list of author information is available at the end of the article
}

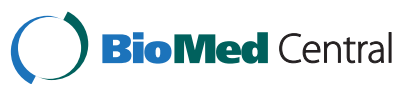

(C) 2015 Breiman et al.; licensee BioMed Central. This is an Open Access article distributed under the terms of the Creative Commons Attribution License (http://creativecommons.org/licenses/by/4.0), which permits unrestricted use, distribution, and reproduction in any medium, provided the original work is properly credited. The Creative Commons Public Domain Dedication waiver (http://creativecommons.org/publicdomain/zero/1.0/) applies to the data made available in this article, unless otherwise stated. 


\section{Background}

Reducing the substantial public health burden of acute respiratory infection in children in Africa remains a major priority and an immense challenge [1,2]. Despite steady advances in characterizing principal etiologies, incidence, and factors contributing to severe respiratory infection [3,4], knowledge gaps persist [5]. Filling these gaps is critical to ensuring that limited available public health resources can be optimally targeted towards feasible, effective interventions. As has been the case for decades [6,7], pneumonia remains a major killer of children in Africa [8,9]. In 2008, it was estimated that 35 million cases of pneumonia occur per year in children $<5$ years old in Africa [3]; it was the cause of $18 \%$ of deaths among African children, resulting in $>750,000$ deaths [1].

Many of the formative studies on pneumonia etiology that provided evidence contributing to design of respiratory disease interventions, were conducted over 20 years ago $[10,11]$. Much has changed over the past two decades. The epidemiology of predisposing conditions for pneumonia, such as malaria, HIV and malnutrition, as well as socioeconomic status, is changing in Africa $[12,13]$. Recent introductions of conjugate vaccines for the two leading bacterial causes of pneumonia, Haemophilus influenzae type B (Hib) and Streptococcus pneumoniae, into the Expanded Programme on Immunization (EPI) in Africa will likely, by reducing the numbers of pneumonias that they cause, also lead to a shifted set of priority pathogens targeted for pneumonia prevention. In addition, new diagnostic technologies, including the advent of more readily available, highly sensitive molecular diagnostics, have enhanced the ability to detect respiratory pathogens $[14,15]$. Finally, with massive urbanization in Africa and advent of densely populated informal settlements or slums [16], different respiratory pathogen transmission patterns [17], co-morbidities, and access to health care $[18,19]$ must be considered when comparing with sparsely populated rural areas from where most data on pneumonia epidemiology and etiology have been collected.

We recently published pneumonia burden and etiology data from population-based surveillance in rural western Kenya undertaken from 2007-2010 [20]. To broaden the knowledge-base and compare etiology and epidemiology, we analyzed data from our population-based infectious disease surveillance (PBIDS) site in Kibera, an urban slum in Nairobi. The rural and urban PBIDS operate with the same study protocol.

\section{Methods}

\section{Study site}

CDC and the Kenya Medical Research Institute (KEMRI) have conducted PBIDS since late 2005 in Kibera, an impoverished informal settlement in Nairobi, Kenya with population density of 77,000 people per $\mathrm{km}^{2}$ and suboptimal hygiene and sanitation [21,22]. All households in 2 villages, Gatwikera and Soweto West were offered enrollment. The mean surveillance population for children $<5$ years old was 5,874 (range $=5,778-6,411$ ) children per month from 2007-2011. Enrollment was continuous since the project's beginning. The under- 5 mortality rate was 15.1 per 1,000 person-years of observation from 2007-2010 [23]. HIV prevalence in the surveillance area is high (14.9\% in adults $\geq 18$ years in 2008) [24]. Pneumococcal conjugate vaccine was not yet introduced during this study period, and vaccine coverage rates for diphtheriapertussis-tetanus vaccine (as part of a pentavalent vaccine) were not available for the study area, but were felt to range between $60-80 \%$ during the study period.

\section{Clinic surveillance}

Since March 1, 2007, all enrolled participants received free medical care for acute illnesses from KEMRI/ CDC-trained clinical staff at Tabitha Clinic (owned by Carolina for Kibera) located $\leq 1 \mathrm{~km}$ from all surveillance households. Tabitha Clinic sees between 90 and 200 out-patients/day and refers all patients requiring hospitalization; it does not have in-patient facilities. Chest radiography was not available through most of the study period.

The clinic-based case definition for SARI for children $<5$ years old used a modification of the WHO Integrated Management of Childhood Illness algorithm for severe and very severe pneumonia, defined as a child with cough or difficulty breathing and any of the following symptoms or signs: unable to drink/breastfeed, vomits everything, convulsions, lethargic or unconscious, stridor when calm, and lower chest wall indrawing $[25,26]$, as well as an additional criterion of oxygen saturation $<90 \%$. Blood cultures and nasopharyngeal and oropharyngeal swabs (polyester-tip) were collected [27] from SARI cases, meeting the above case definition; however, specimens were not collected from a substantial proportion of patients during periods of under-staffing, high patient volume, or if parents/ caretakers did not want to have specimens obtained. Clinical differences by age group between children with SARI who were swabbed and not swabbed are shown in Tables 1 and 2.

\section{Household surveillance}

Community interviewers visited enrolled households every two weeks and questioned surveillance participants using a standardized questionnaire about recent illnesses, including symptoms and health-seeking, and performed a limited exam on those with symptoms [20]. We defined SARI from the household visits as cough or difficulty breathing with either chest indrawing or elevated respiratory rate for age [20]. 
Table 1 Age and gender of children with SARI from whom respiratory swabs were collected or not collected

\begin{tabular}{|c|c|c|}
\hline \multirow[t]{2}{*}{ Characteristic } & \multicolumn{2}{|l|}{ Number (Row \%) } \\
\hline & Swabbed $(\mathrm{N}=815)$ & Not Swabbed $(\mathrm{N}=1777)$ \\
\hline \multicolumn{3}{|l|}{ Age } \\
\hline$<12 \mathrm{~m}(\mathrm{~N}=980)$ & $285(29.1 \%)$ & $695(70.9 \%)$ \\
\hline $12-23 m(N=718)$ & $241(33.6 \%)$ & $477(66.4 \%)$ \\
\hline $24-59 \mathrm{~m}(\mathrm{~N}=894)$ & $289(32.3 \%)$ & $605(67.7 \%)$ \\
\hline Total $(N=2592)$ & $815(31.4 \%)$ & 1777 (68.6\%) \\
\hline \multicolumn{3}{|l|}{ Gender } \\
\hline Male $(N=1369)$ & $411(30.0 \%)$ & $958(70.0 \%)$ \\
\hline Female $(N=1223)$ & $404(33.0 \%)$ & $819(67.0 \%)$ \\
\hline
\end{tabular}

\section{Control selection}

From January 1, 2009-February 28, 2011, asymptomatic control-children were enrolled from Tabitha Clinic. Eligible controls were those who presented with nonsevere illness (i.e. not requiring hospitalization), for immunizations, or for medicine refills, as described [20]. Eligible controls could not have had fever, any respiratory symptoms or diarrhea during the preceding two weeks. Each month, we attempted to enroll up to six controls $<2$ years old, and up to six controls 2-4 years old, frequency-matched to cases by known HIV status; however, this target was not met every month. Nasopharyngeal and oropharyngeal swabs were collected from control-children. Ages of controls (mean 2.0, median 1.8) were similar to those of cases (mean 1.7, median 1.5). Controls were not enrolled if there was a SARI case-patient from the same household enrolled on the same day.

Table 2 Clinical characteristics of children with SARI from whom swabs were collected and not collected

\begin{tabular}{|c|c|c|c|c|c|}
\hline & \multicolumn{2}{|c|}{$\begin{array}{l}\text { Swabbed } \\
(\mathrm{N}=815)\end{array}$} & \multicolumn{2}{|c|}{$\begin{array}{l}\text { Not Swabbed } \\
(\mathrm{N}=1,777)\end{array}$} & \multirow[t]{2}{*}{ P-value } \\
\hline & $\mathrm{n}$ & $\%$ & $\mathrm{n}$ & $\%$ & \\
\hline Cough & 806 & 98.9 & 1747 & 98.3 & 0.91 \\
\hline Difficulty Breathing & 435 & 53.3 & 575 & 32.4 & $0.003^{*}$ \\
\hline Unable to Drink or Breastfeed & 0 & 0 & 2 & 0.1 & 0.57 \\
\hline Vomits Everything & 155 & 19.0 & 338 & 19.0 & 0.97 \\
\hline Lethargy & 28 & 3.4 & 93 & 5.2 & 0.53 \\
\hline Chest Indrawing & 616 & 75.6 & 586 & 33.0 & $<0.001^{*}$ \\
\hline Stridor & 21 & 2.6 & 80 & 4.5 & 0.47 \\
\hline Oxygen Saturation Measured & 808 & 99.1 & 1755 & 98.8 & 0.99 \\
\hline Oxygen Saturation $\leq 90 \%$ & 155 & 19.0 & 761 & 42.8 & $<0.001^{*}$ \\
\hline Temperature $\geq 38^{\circ} \mathrm{C}$ & 447 & 54.9 & 492 & 27.7 & $<0.001^{*}$ \\
\hline Temperature $\geq 39^{\circ} \mathrm{C}$ & 162 & 19.9 & 142 & 8.0 & $0.02^{*}$ \\
\hline $\begin{array}{l}\text { Death within } 14 \text { days following } \\
\text { clinic visit }\end{array}$ & 4 & 0.5 & 8 & 0.5 & 0.9 \\
\hline
\end{tabular}

*Significant at $p<0.05$.

\section{Laboratory testing}

Clinic staff trained in phlebotomy collected one to three $\mathrm{mL}$ of blood for culture which was inoculated into commercially-produced blood culture bottles. Bacterial growth was identified using standard methodology, described previously (BACTEC ${ }^{\mathrm{ma}}$ Aerobic Pedi-PLUS ${ }^{\mathrm{mm}}$, Becton Dickinson, Belgium) [28].

Nasopharyngeal and oropharyngeal swabs from cases and controls were combined into $1 \mathrm{ml}$ of viral transport media without antibiotics and transported the same day at $2^{\circ} \mathrm{C}-8^{\circ} \mathrm{C}$ to KEMRI/CDC laboratories in Nairobi ( $<30$ minutes by automobile), where each specimen was divided into four aliquots and stored at $-70^{\circ} \mathrm{C}$ until testing. Total nucleic acid was extracted from $100 \mu$ of each specimen using MagMAX Viral RNA Isolation Kit (Applied Biosystems) and immediately tested with quantitative real-time reverse transcription polymerase chain reaction (qRT-PCR) assays for adenovirus, respiratory syncytial virus (RSV), human metapneumovirus (hMPV), influenza types A and B viruses, and parainfluenza viruses 1-3 (PIV), as described [20]; A qRT-PCR test result was considered positive if an exponential fluorescence growth curve was detected with an assigned cycle threshold $\left(\mathrm{C}_{\mathrm{T}}\right)$ value $<40.0[29,30]$. Each clinical specimen was also tested by qRT-PCR for the human ribonuclease $\mathrm{P}$ gene to measure nucleic acid integrity and to confirm sample adequacy.

Respiratory swab specimens collected between January 1, 2009 and February 28, 2010 were tested for three additional viruses (rhinovirus, enterovirus, and parechovirus) and atypical bacteria. Total nucleic acid extracts from these specimens were shipped on dry ice from Nairobi to CDC, Atlanta, for testing specifically for the viral pathogens; all other testing throughout the study was done at KEMRI/CDC. qRT-PCR assays for rhinovirus, enterovirus and parechovirus were performed using previously published methodologies [31-33]. The rhinovirus and enterovirus assays target an area of the 5 noncoding region of an area with high sequence similarity between the viruses that results in some cross-reactivity [34]. Therefore, positive rhinovirus and/or enterovirus qRT-PCR were reported together as rhinovirus/enterovirus positive. For atypical bacteria, multiplex qRT-PCR was performed at KEMRI/ CDC laboratories in Nairobi for Mycoplasma pneumoniae, Chlamydophila pneumoniae and pan-Legionella species (atypical bacteria) using published assays [35]. Neither HIV nor tuberculosis testing was routinely done on children with SARI at the clinic.

\section{Data analysis}

Analyses were performed using SAS (version 9.2, Cary, NC). Proportions were compared using Pearson's chisquare or Fisher's exact tests (for small cell counts). Rate ratios and 95\% confidence intervals were calculated 
using Fisher's method (Computer Programs for Epidemiologists, PEPI, version 4.0x) for crude rates. The Delta method was used for calculating confidence intervals for the adjusted rates taking into account the variation in SARI case numbers, the variation in the adjustment due to clinic visitation, the variation in estimating the proportion of SARI with pathogen detected, and the variation in the pathogen attributable fraction (PAF) estimates (see below) [36].

We compared detection of each virus by qRT-PCR from swabs between cases and asymptomatic controls for the period of January 1, 2009, - Feb 28 2011. Odds ratios (OR) and $95 \%$ confidence intervals were calculated using unconditional logistic regression, adjusting for age group (0-11, 12-23, 24-59 months) and season when the swab was taken (December-February, hot and dry; March-May and September-November, the two rainy seasons; and June-August, cool). We used ORs to calculate PAF, which estimates the proportion of cases positive for each virus in which the virus is the likely cause $[20,37,38]$. The PAFs, calculated as (OR-1)/OR, were only calculated for viruses with ORs that were $>1.0$. For purposes of this analysis, we assumed the PAF was 1.0 for bacteria detected by blood culture based on the negligible probability of detection of pathogenic bacteria in blood of asymptomatic controls.

SARI incidence was calculated as the number of SARI clinic visits per 100 person-years of observation for the period March 1, 2007-Feb 28, 2011. Revisits for the same illness episode ( $<7$ days respiratory symptom free) were not counted separately. Permanent residence status in the surveillance area was used to determine person-time contribution, as described [39]. Adjusted rates of clinic visitation were calculated accounting for the percentage of all clinic visits made for SARI that were to the Tabitha Clinic (the only clinic in the area where standardized data collection on SARI was done), as opposed to visits to other area clinics, as determined from the household visit interviews [21]. We used any clinic visit as a marker of serious illness, assuming that many illnesses for which no clinic visit was made were likely less severe. Etiologyspecific adjusted incidence was calculated by applying the proportions of each etiology to the adjusted incidence of SARI, as shown:

$$
\begin{aligned}
\mathrm{I}_{\mathrm{SARIz}}= & \left(\left(\mathrm{Num}_{\mathrm{SARI}} /(\mathrm{SCV} / \mathrm{ACV})\right) \times(\mathrm{Z} / \mathrm{SARI}) \times \mathrm{PAF}\right) / \mathrm{PYO} \\
& \times 100
\end{aligned}
$$

Where

$\mathrm{I}_{\text {SARIz }}=$ Incidence of SARI due to pathogen $\mathrm{z}$ (per 100 child-years).

Num$_{\text {SARIz }}=$ number of SARI cases detected at the clinic during the study period.
SCV/ACV = SARI episodes associated with visiting the study clinic (SARI Clinic Visits or SCV) divided by SARI episodes associated with visiting any clinic (any clinic visits or ACV) (from household visit data).

$\mathrm{Z} / \mathrm{SARI}=$ Proportion of SARI cases from which pathogen $\mathrm{z}$ is detected.

$\mathrm{PAF}=(\mathrm{OR}-1) / \mathrm{OR}$.

$\mathrm{PYO}=$ Person-years of observation .

Etiology-specific incidence was only calculated for pathogens with an OR $\geq 1.0$ in the case-control analysis. We also calculated incidence for pathogens of the same genus or sub-family (i.e. all influenza viruses and all parainfluenza viruses).

We calculated a SARI etiologic fraction (SEF) (also known as population attributable fraction) for each pathogen for which incidence was measured (above) [40,41]. For this analysis, SEF is the proportion of SARI cases that might theoretically be eliminated if the etiology were eliminated (assuming a primary role for that etiologic pathogen in causing pneumonia). SEF is given as:

$$
\mathrm{SEF}=(\mathrm{Z} / \mathrm{SARI}) \times(\mathrm{PAF})
$$

where Z/SARI and PAF are calculated as in the previous equation. To attempt to calculate PAFs adjusting for multiple pathogens (co-infections), we fit a logistic regression model including the pathogens, all pairwise interaction terms for the pathogens, and age and seasonality; the outcome variable for the model was case/control status ( 1 for case and 0 for control). The RSV and any parainfluenza interaction variable and the RSV and adenovirus interaction variable were borderline significant; all other pathogen interaction variables were non-significant. However, neither of these interaction variables was synergistic in SARI cases (one pathogen being more likely to be found when the other is present). The opposite was truethe second pathogen was less likely to be found in SARI cases when the other pathogen was present. Therefore, we simply present PAFs, adjusting only for age and seasonality.

\section{Ethical review}

Written informed consent was obtained for data collection at the clinics and households. The protocol and consent forms were reviewed and approved by the Institutional Review Boards of KEMRI (\#932) and CDC (\#4566).

\section{Results}

A total of 2,592 children $<5$ years old with SARI were evaluated at the clinic from March 1, 2007-February 28, $2011 ; 815$ (31.4\%) had nasopharyngeal/oropharyngeal swab specimens collected. Of these, $34.8 \%$ were infants (<12 months old), $29.5 \%$ were $12-23$ months old, and 
35.7\% were 24-59 months old (Table 1). Children with SARI who were swabbed were more likely to be febrile and to have difficulty breathing and chest indrawing than children who were not swabbed (Table 2). Among infants $<1$ year of age with SARI, the most commonly detected viruses in nasopharyngeal/oropharyngeal specimens were rhinovirus/enterovirus (42\%), RSV (25\%), adenovirus (20\%), and human hMPV (13.7\%) (Table 3). In toddlers 12-23 months old, enterovirus/rhinovirus (49\%), adenovirus (31.5\%). RSV (20.3\%) and influenza
A $(10.8 \%)$ were the top four viruses detected, and in children 24-59 months old, the top four pathogens detected were rhinovirus/enterovirus (53\%), adenovirus (36.9\%), RSV (15.8\%), and influenza A (13.4\%) (Table 3). Atypical bacteria were not detected in any specimens. Overall, a potential pathogen was not detected in respiratory secretions from $29 \%$ of cases.

Among 836 uncontaminated blood cultures processed from children with SARI, a pathogen was isolated from 41 (4.9\%). Staphylococcus aureus (1.7\%) was the most

Table 3 Etiologies of SARI in children $<5$ years old, by age group, in Kibera, Nairobi, Kenya

\begin{tabular}{|c|c|c|c|c|}
\hline & $<1$ year $\mathrm{n}(\%)$ & $12-23$ months $\mathrm{n}(\%)$ & 24-59 months n (\%) & All cases, $\mathrm{n}(\%)$ \\
\hline Total patients seen & 12445 & 11838 & 21385 & 45668 \\
\hline SARI cases & $980(7.9 \%)$ & $718(6.1 \%)$ & $894(4.2 \%)$ & $2592(5.7 \%)$ \\
\hline Rate of SARI (per 100 PYO) & 30.4 & 16.7 & 6.7 & 12.4 \\
\hline CFR $^{a}$ for SARI cases & $13(1.3 \%)$ & $2(0.3 \%)$ & $3(0.3 \%)$ & $18(0.7 \%)$ \\
\hline Blood cultures (BC) done & $270(27.6 \%)$ & $243(33.8 \%)$ & 349 (39.0\%) & $862(33.3 \%)$ \\
\hline BCs without contaminant & $259(26.4 \%)$ & $236(32.9 \%)$ & $341(38.1 \%)$ & $836(32.3 \%)$ \\
\hline S. pneumoniae & $4(1.5 \%)$ & $3(1.3 \%)$ & $1(0.3 \%)$ & $8(1 \%)$ \\
\hline H. influenzae $e^{b}$ & 0 & 0 & 0 & 0 \\
\hline S. aureus ${ }^{b}$ & $10(3.9 \%)$ & $1(0.4 \%)$ & $3(0.9 \%)$ & $14(1.7 \%)$ \\
\hline Klebsiella pneumoniae $^{\mathrm{b}}$ & 0 & 0 & 0 & 0 \\
\hline Non-typhi Salmonella ${ }^{b}$ & $7(2.7 \%)$ & $3(1.3 \%)$ & $3(0.9 \%)$ & $13(1.6 \%)$ \\
\hline Salmonella Typhi & $1(0.4 \%)$ & $2(0.8 \%)$ & $2(0.6 \%)$ & $5(0.6 \%)$ \\
\hline Other pathogenic bacteria ${ }^{b, c}$ & 0 & 0 & $1(0.3 \%)$ & $1(0.1 \%)$ \\
\hline Naso/oropharyngeal swabs collected & $285(29.1 \%)$ & $241(33.6 \%)$ & $289(32.3 \%)$ & $815(31.4 \%)$ \\
\hline Influenza A & $27(9.4 \%)$ & $26(10.8 \%)$ & $39(13.5 \%)$ & $92(11.3 \%)$ \\
\hline Influenza B & $4(1.4 \%)$ & $6(2.5 \%)$ & $11(3.8 \%)$ & $21(2.6 \%)$ \\
\hline Influenza A or B & $31(10.9 \%)$ & $31(12.9 \%)$ & $50(17.1 \%)$ & $112(13.7 \%)$ \\
\hline Respiratory syncytial virus & $74(25.9 \%)$ & $49(20.3 \%)$ & $46(15.8 \%)$ & 169 (20.7\%) \\
\hline Adenovirus & $57(20 \%)$ & $76(31.5 \%)$ & $108(36.9 \%)$ & $241(29.5 \%)$ \\
\hline Parainfluenza virus 1 & $10(3.5 \%)$ & $10(4.1 \%)$ & $8(2.7 \%)$ & $28(3.4 \%)$ \\
\hline Parainfluenza virus 2 & $7(2.5 \%)$ & $7(2.9 \%)$ & $11(3.8 \%)$ & $25(3.1 \%)$ \\
\hline Parainfluenza virus 3 & $31(10.9 \%)$ & $27(11.2 \%)$ & $19(6.5 \%)$ & $77(9.4 \%)$ \\
\hline Any Parainfluenza & $46(16.1 \%)$ & $43(17.8 \%)$ & $34(11.6 \%)$ & $123(15.0 \%)$ \\
\hline Human metapneumovirus & $39(13.7 \%)$ & $23(9.5 \%)$ & $35(11.9 \%)$ & $97(11.9 \%)$ \\
\hline Rhinovirus/Enterovirus $^{d}$ & $32 / 76(42 \%)$ & $36 / 73(49 \%)$ & $29 / 55(53 \%)$ & $97 / 204(47.5 \%)$ \\
\hline Parechovirus $^{\mathrm{d}}$ & $3 / 76(4 \%)$ & 0 & $1 / 55(1.8 \%)$ & $4(2.0 \%)$ \\
\hline Atypical bacteria $^{\mathrm{e}}$ & 0 & 0 & 0 & 0 \\
\hline Positive $>=1$ virus & 204 (71.6\%) & $182(75.5 \%)$ & $195(66.8 \%)$ & $581(71.0 \%)$ \\
\hline Positive $>=2$ virus & 71 (24.9\%) & $67(27.8 \%)$ & $83(28.4 \%)$ & $221(27.0 \%)$ \\
\hline
\end{tabular}

All data presented as number and percentage in parentheses rounded to the nearest integer.

${ }^{a}$ Case-fatality ratios (CFR) are defined as death in the 30 days following clinic visit for SARI episode.

${ }^{\mathrm{b}}$ Denominator $=$ uncontaminated blood cultures from 836 patients. Blood culture results discarded if they contained coagulase-negative Staphylococcus, Bacillus species, or Corynebacteria.

'Other pathogenic bacterium was Escherichia coli.

${ }^{d}$ Rhino/enterovirus, parechovirus, and atypical bacteria were only tested for from January 1, 2009 - February 28, $2010 ; 204$ swabs were tested among persons $<5$ years old (76 specimens in $<1$ year olds, 73 on 12-23 month olds and 55 in 24-59 month olds).

epresence of atypical bacteria (Mycoplasma pneumoniae, Chlamydophila pneumoniae, and Legionella species) was assessed by qPCR in 76 np/op swabs. March 1, 2007-February 28, 2011. 
common species isolated, followed by non-Typhi Salmonella (NTS) species (1.6\%), Streptococcus pneumoniae (1\%) and Salmonella Typhi (0.6\%) (Table 3).

When comparing detection rates from respiratory swabs in SARI cases and healthy controls, RSV and influenza A were significantly associated with being a case (Table 4). Several viruses (parainfluenza 1 and 3, and hMPV, influenza B, and adenovirus) were associated with adjusted odds ratios $\geq 1.5$, but the differences between cases and controls were just outside of statistical significance (Table 3). All of the other viruses tested were also found more often in cases than controls with none of these differences approaching statistical significance. Having at least one virus detected from swabs was strongly associated with cases, as was having $\geq 2$ viruses detected (Table 4).

Taking the proportion of SARI cases from which a pathogen was detected and the PAF, we calculated the SARI etiologic fraction (see Methods) attributed to viruses or groups of viruses. RSV accounted for the highest etiologic fraction (16.2\%) of SARI cases in children $<5$ years old, followed by adenoviruses (10.6\%), parainfluenza viruses (7.0\%), and influenza A and B combined (6.7\%), and hMPV (6.3\%). Since the odds ratios upon which the SARI etiologic fractions were based were significant only for RSV and influenza viruses, the etiologic fractions for the

Table 4 Naso/oropharyngeal swab test results from cases and controls

\begin{tabular}{|c|c|c|c|}
\hline Pathogen & $\begin{array}{l}\text { Cases, } \mathrm{n}(\%) \\
\mathrm{N}=731\end{array}$ & $\begin{array}{l}\text { Controls, n (\%) } \\
\mathrm{N}=115\end{array}$ & $\begin{array}{l}\text { Adjusted OR** } \\
(95 \% \mathrm{Cl})\end{array}$ \\
\hline Influenza A & $79(10.8 \%)$ & $5(4.3 \%)$ & $2.57(1.01-6.52)$ \\
\hline Influenza B & $19(2.6 \%)$ & $1(0.9 \%)$ & $3.06(0.41-23.17)$ \\
\hline Influenza A or B & $97(13.3 \%)$ & $6(5.2 \%)$ & $2.71(1.15-6.39)$ \\
\hline $\begin{array}{l}\text { Respiratory } \\
\text { syncytial virus }\end{array}$ & 155 (21.2\%) & $3(2.6 \%)$ & $10.15(3.16-32.58)$ \\
\hline Adenovirus & $221(30.2 \%)$ & $27(23.5 \%)$ & $1.51(0.94-2.42)$ \\
\hline Parainfluenza virus 1 & $26(3.6 \%)$ & $1(0.9 \%)$ & $4.12(0.55-30.69)$ \\
\hline Parainfluenza virus 2 & $24(3.3 \%)$ & $5(4.3 \%)$ & $0.71(0.26-1.9)$ \\
\hline Parainfluenza virus 3 & $72(9.8 \%)$ & $5(4.3 \%)$ & $2.31(0.91-5.85)$ \\
\hline Any parainfluenza & $115(15.7 \%)$ & $10(8.7 \%)$ & $1.87(0.95-3.69)$ \\
\hline Human metapneumovirus & $91(12.4 \%)$ & $7(6.1 \%)$ & $2.12(0.96-4.72)$ \\
\hline Atypical bacteria & $0(0 \%)$ & $0(0.0 \%)$ & - \\
\hline $\begin{array}{l}\text { Rhinovirus/ } \\
\text { Enterovirus * }\end{array}$ & $97(47.5 \%)$ & $24(50.0 \%)$ & $0.89(0.46-1.71)$ \\
\hline Parechovirus * & $4(1.9 \%)$ & $1(2.1 \%)$ & $0.73(0.08-6.85)$ \\
\hline Positive $>=1$ virus & $533(72.9 \%)$ & $61(53 \%)$ & $2.27(1.51-3.42)$ \\
\hline Positive $>2$ viruses & 207 (28.3\%) & 17 (14.8\%) & $2.36(1.36-4.11)$ \\
\hline
\end{tabular}

*Rhino/enterovirus, parechovirus and atypical bacteria were only tested among a subset of patients. 204 swabs cases were tested among cases $<5$ years old; 48 controls were tested.

**adjusted for age group (0-11, 12-23, 24-59 months) and season during which the swab was taken.

January 1, 2009, - Feb 282011 Kibera, Nairobi Kenya. other three pathogens are point estimates (totalling 23.9\%) and must be viewed with some caution; however, given an array of co-factors which contribute to the risk of pneumonia, it is conceivable that these pathogens are important in chains of causation. Overall, $46.8 \%$ of SARI cases had an independently attributable viral etiology. When blood culture results were included (without regard to blood culture sensitivity), $51.8 \%$ of episodes of SARI had an attributable pathogen.

The overall incidence of SARI was 12.4 cases/100 PYO; infants had the highest incidence (30.4 cases/100 PYO). The highest pathogen-specific adjusted incidence rate was with RSV (2.8 cases/100 PYO) (Table 5). The adjusted incidence for influenza A was 1.0 cases/100 PYO and for influenza A and B combined 1.3 cases $/ 100$ PYO (Table 5). The rate for parainfluenza virusassociated SARI was 1.1 case/100 PYO and the rates for adenovirus-associated or hMPV-associated SARI were 1.5 and 0.9 case per 100 PYO, respectively.

During the four year study period, RSV primarily occurred during January through April (peaking in March and April) (Figure 1), a warm and dry, pre-rainy season in Nairobi. Influenza A was detected year round with a peak from October through December, a rainy season, and a smaller peak in June and July, the cold season. While adenoviruses were detected year round, two peaks occurred, from January through March, and September through December. Other pathogens were detected at low frequency every month.

\section{Discussion}

This study characterizes the incidence of major respiratory viral pathogens as causes of SARI in children. Because of insensitivity of diagnostic tests for bacteria, the roles of key bacterial etiologies were likely underestimated. The rates for SARI are lower than what we observed in a similar study conducted over the same time interval in a rural, sparsely populated area of Kenya (Lwak) about $250 \mathrm{~km}$ away by road, which also found that influenza A and RSV were significant contributors to SARI (20). Both areas have high HIV seroprevalence in adults (15-20\%) (24), but the rural area is holoendemic with malaria (which can present as SARI [42]), whereas in Kibera local transmission of malaria is felt to be low.

The case definition we used for SARI is similar to definitions used for severe and very severe pneumonia by WHO and for ALRI, the only difference being that we added a clinical criterion of oxygen saturation $<90 \%$ to add some specificity for severe disease. Thus, the incidence data from this study should be interpretable within the context of other reports of severe and very severe pneumonia and of acute lower respiratory infection in children with the caveat that the study clinic only 
Table 5 Incidence of select pathogens associated with SARI case status among children < 5, Kibera, Kenya

\begin{tabular}{|c|c|c|c|c|c|c|c|}
\hline Pathogen & $\begin{array}{l}\text { \% SARI with } \\
\text { pathogen detected } \\
\text { (from Table 3) }\end{array}$ & $\begin{array}{l}\text { Pathogen } \\
\text { specific-Number } \\
\text { of SARI cases }^{\mathrm{a}}\end{array}$ & $\begin{array}{l}\text { Proportion of } \\
\text { all clinic visits } \\
\text { for SARI that } \\
\text { went to study } \\
\text { clinic }\end{array}$ & $\begin{array}{l}\text { Adjusted No. of } \\
\text { Pathogen } \\
\text { specific-SARI } \\
\text { cases }^{b}\end{array}$ & $\mathrm{PAF}^{\mathrm{c}}$ & $\begin{array}{l}\text { Final Adjusted } \\
\text { Number of Cases }^{d}\end{array}$ & $\begin{array}{l}\text { Rate/100PYO } \\
(95 \% \mathrm{Cl})\end{array}$ \\
\hline Influenza A & $11.2 \%$ & 290 & 0.82 & 354 & 0.64 & 227 & $1.0(0.4-1.7)$ \\
\hline $\begin{array}{l}\text { Influenza A and } \\
\text { B combined }\end{array}$ & $13.7 \%$ & 355 & 0.82 & 433 & 0.64 & 277 & $1.3(0.6-2.0)$ \\
\hline $\begin{array}{l}\text { Respiratory } \\
\text { syncytial virus }\end{array}$ & $20.7 \%$ & 537 & 0.82 & 654 & 0.90 & 589 & $2.8(2.4-3.2)$ \\
\hline S. pneumoniae & $1 \%$ & 23 & 0.82 & 28 & 1.00 & 28 & $0.1(0.1-0.2)$ \\
\hline S. aureus & $1.7 \%$ & 41 & 0.82 & 51 & 1.00 & 51 & $0.2(0.2-0.3)$ \\
\hline Non-typhi Salmonella & $1.6 \%$ & 39 & 0.82 & 47 & 1.00 & 47 & $0.2(0.2-0.3)$ \\
\hline Salmonella Typhi & $0.6 \%$ & 18 & 0.82 & 22 & 1.00 & 22 & $0.1(0.1-0.2)$ \\
\hline Influenza B & $2.6 \%$ & 67 & 0.82 & 82 & 0.57 & 47 & $0.3(0.0-0.5)$ \\
\hline Adenovirus & $29.5 \%$ & 765 & 0.82 & 932 & 0.36 & 336 & $1.5(0.1-2.9)$ \\
\hline $\begin{array}{l}\text { Parainfluenza } \\
\text { virus } 1\end{array}$ & $3.4 \%$ & 88 & 0.82 & 107 & 0.77 & 83 & $0.4(0.1-0.7)$ \\
\hline $\begin{array}{l}\text { Parainfluenza } \\
\text { virus } 3\end{array}$ & $9.4 \%$ & 244 & 0.82 & 297 & 0.55 & 163 & $0.8(0.2-1.4)$ \\
\hline Any parainfluenza & $15.0 \%$ & 389 & 0.82 & 474 & 0.46 & 218 & $1.1(0.2-1.9)$ \\
\hline Human metapneumovirus & $11.9 \%$ & 308 & 0.82 & 376 & 0.53 & 199 & $0.9(0.3-1.6)$ \\
\hline
\end{tabular}

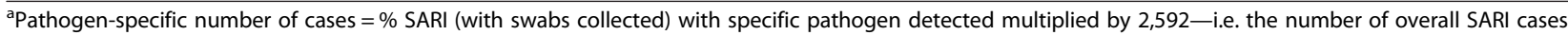
(with and without swabs collected).

${ }^{\mathrm{b}}$ Adjusted number of pathogen-specific SARI cases = Pathogen specific number of SARI cases/0.82 (Proportion of all clinic visits for SARI that were to study clinic). 'PAF = Pathogen Attributable Fraction (see methods).

${ }^{d}$ Final adjusted number of cases $=$ Adjusted No. of pathogen specific-SARI cases multiplied by PAF.

'Rates calculated per 100 person-years of observation.

March 1, 2007-February 28, 2011.

serves outpatients, referring severely ill children to a nearby hospital; therefore, the clinical spectrum likely differed from studies of hospitalized SARI patients. However, children with signs of severe illness (like chest indrawing, difficulty breathing and high fever) were more likely to be sampled while those with low oxygen saturation were not.
Decades of research have consistently found RSV to be the most important viral pathogen causing significant acute respiratory illness in infants and young children $[2,5,10,43]$. A recent meta-analysis of published and unpublished data found that the incidence of RSV-associated severe ALRI has ranged from 10-18 per 1000 children/ year for infants and 3-9 per 1000 per children $<5$ years of

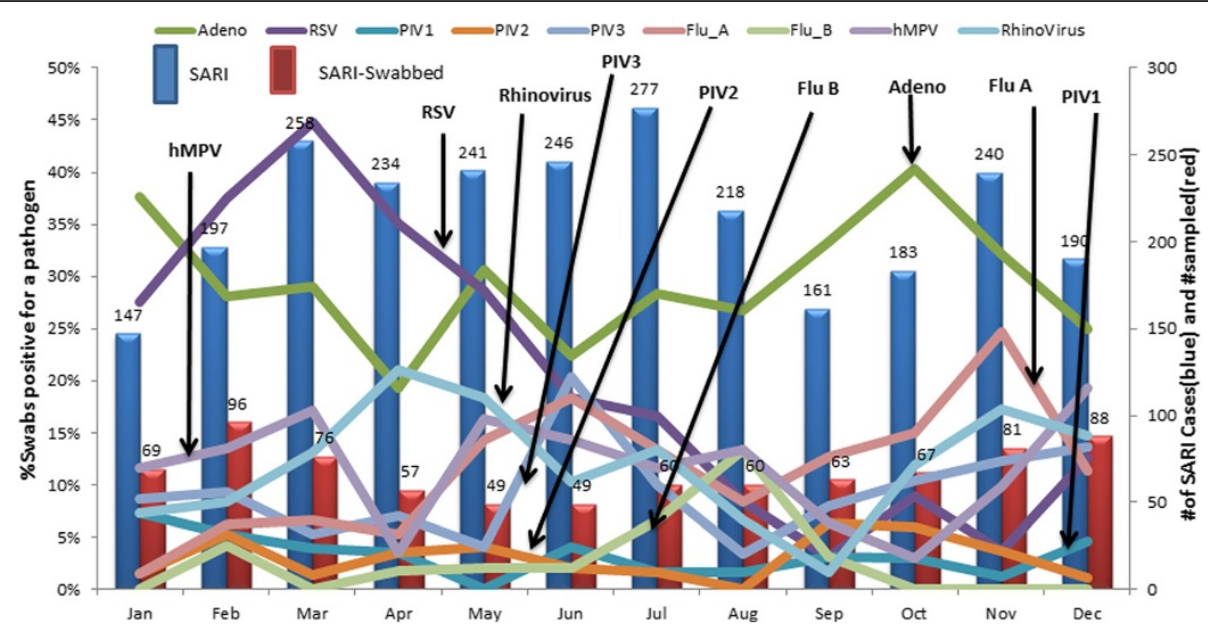

Figure 1 Monthly (aggregate) distribution of viral pathogens, March 1, 2007-Feb 28, 2011. 
age/year in Africa, with most data coming from passive, hospital-based surveillance with defined catchment areas [44]. These rates were much lower than those found in Alaska and among the Navajo and White Mountain Apache population in the US and in a site in Guatemala [44]; it is unclear whether the differences are due to ecological variations or methodological differences. The rates from Kibera for RSV-associated SARI, resulting from active, community-based surveillance, which made it possible to account for cases missed during clinic surveillance, were slightly higher than the rates from the earlier African studies, but lower than the rates we found in the parallel rural study [20]. Our rural study clinic included in-patients, which increased the likelihood of including sicker patients, than in Kibera, where very sick patients may have chosen to go directly to hospital. The rates from both studies likely underestimate RSV (and other SARI) incidence because we only adjusted for that portion of patients who went to a clinic other than the study clinic; we did not adjust for under-utilization of any clinical services, which is a factor to consider in both the urban and rural sites $[17,18]$.

Over the past decade, the number of studies of influenza has accelerated in sub-Saharan Africa [45]; data from 15 countries from 2006-2010, including Kenya (but not Kibera) showed that (without controls) 10\% of SARI cases $<5$ years old had evidence of influenza infection [46], which was similar to what we observed in Kibera. A meta-analysis of published and unpublished global data, including 2008 data from the Kibera site (among many others), found a rate of influenza associated ALRI of 14/1000 children $<5$ years old in developing countries [47], imputing that 111,500 deaths due to influenza (range $=21,000-245,000$ ) occurred in 2008. As documented in other tropical environments [48], influenza in Kibera appeared to be a year-round phenomenon without a predominant occurrence in cool months.

Specimens from cases alone would have suggested that rhinoviruses were the most important viruses for SARI in all three age groups; however, rhinoviruses were detected more often from control specimens. This study does not rule out a role for human rhinoviruses in SARI, however, as nasopharyngeal specimens are not consistently the optimal sample for determining the cause of lung pathology. A recent outbreak of fatal respiratory infection in infants in Vietnam was attributed to a subclade of a genotypically distinct cluster of rhinoviruses [49], and earlier reports have documented association of specific genotypes of rhinoviruses with ALRI [50,51]. We did not assess the genotype of the rhinoviruses detected in this study to determine if there were specific rhinovirus clusters associated with illness when compared with controls.
M. pneumoniae and C. pneumoniae were not detected in any specimens; their role in SARI in children in the developing world is unclear. A recent study from Madagascar detected $M$. pneumoniae and C. pneumoniae within a small subset of children with respiratory illness, without a healthy control group for comparison [52] and a prospective study in Tunisia suggested that $M$. pneumoniae was the cause of $>7 \%$ of hospitalized pneumonias in children [53].

While our studies and others have consistently shown that influenza A and RSV are important contributors to SARI in children, our data also suggest that when considered together, PIV, adenovirus and hMPV play a causal role for approximately $24 \%$ of SARI cases with the caveat that statistical significance when comparing cases and controls was not quite achieved for these viruses. The 3 viruses are likely important pathogens to consider when developing technologies and packaging strategies to prevent severe acute respiratory illness. However, it should be noted that because of frequent adenovirus infection in early childhood and persistent shedding, many detections of adenovirus by rRT-PCR could represent prevalent rather than incident infections [54].

There appeared to be a broader range of viruses causing SARI in Kibera when compared with our rural site in Lwak [20] and with a recent study conducted in rural Kilifi, Kenya, which also only found significantly greater detection of RSV when comparing pneumonia cases with controls [55]. In our rural study, which was conducted for a shorter, overlapping interval, all odds ratios were $\leq 1.3$ (with wide confidence intervals) for each of the same viruses tested as in Kibera, except for the odds ratio associated with infection with PIV-2 (OR $=2.6 ; 95 \%$ $\mathrm{CI}=0.6-10.0)$. While it is tempting to hypothesize that the population density in Kibera when compared to the rural site $\left(300\right.$ people $\left./ \mathrm{km}^{2}\right)$ provides a more dynamic "melting pot" for virus introduction and spread, we have insufficient additional evidence to support the notion.

We used blood culture to document invasive bacterial infection in patients with SARI. The highly specific results are, nonetheless, very insensitive. No sensitive tests for S. pneumoniae and other bacterial pathogens are currently available. However, historical data and vaccine probe studies [56] have shown that a substantial proportion (10-20\%) of SARI was likely due to pneumococcal infection; thus, the rate we found (shown in Table 3) substantially underestimates the rate of $S$. pneumoniaeassociated SARI. Since Hib vaccine is given routinely in Kenya, Hib was likely not an important contributor to SARI incidence. We detected NTS and Salmonella Typhi in blood culture from only a few patients. However, given the importance of NTS and S. Typhi as causes of acute febrile illness often with respiratory symptoms, in some settings $[39,57]$, it is worthwhile to be aware of their potential role. The impact of these 
pathogens may change, especially with urbanization and growth in slums, which especially appears to increase the risk for typhoid fever [39]. The data from this study are consistent with a study from South Africa suggesting that $S$. aureus may be an important cause of pneumonia in children [58]; in that study, there was a potential link to HIV infection. In an urban setting in Nigeria, S. aureus was the most common cause of bacteremia in children with pneumonia [59]. More data are needed to characterize the burden, co-morbidities and other risk factors for children with $S$. aureus bacteremiaassociated SARI, recognizing the potential that some of the microbiological results may represent contamination.

By calculating etiologic fractions for SARI, approximately one-half of SARI cases are accountable with the pathogens we studied. If one assumes, based on pneumococcal vaccine probe data $[56,60]$ that approximately $25 \%$ of SARI (based on a $12 \%$ reduction in severe pneumonia and a $50 \%$ vaccine efficacy against all pneumococcal serotypes from vaccine studies) is due to $S$. pneumoniae, then up to $75 \%$ of SARI episodes might be attributable to a specific etiologic agent. Thus, we could not attribute illness to a specific pathogen in at least $25 \%$ of cases. The most likely explanation for this diagnostic gap is insensitivity of diagnostic tests and type of specimens- nasopharyngeal and oropharyngeal swabs are not the most efficient techniques for capturing all respiratory viruses [61] and are not appropriate for detecting key bacterial etiologies of pneumonia. Timing of specimen collection vis-à-vis peaks in virologic shedding may also have played role. It is also likely that pathogens other than the ones we tested for (possibly including pathogens not yet known) caused a proportion of these illnesses, and will become important public health targets in the future as new diagnostic tests become available and, also, potentially as new pathogens are recognized. In addition, clinical syndromes, like malaria, can masquerade as pneumonia, thus accounting for a proportion of the "non-attributable causes."

There were a number of limitations associated with the findings of this investigation. We were limited in this analysis by the small number of controls. This restricted the precision of our estimates of pathogen attributable fraction; consequently, we could not confirm the precise role of several pathogens that may be important contributors to the burden of SARI. In addition, quantifying the viral load in respiratory secretions (which we did not do in this analysis) could potentially identify a threshold of pathogen load associated with illness versus asymptomatic colonization [62,63]. Also, we did not test for other pathogens that might contribute to the incidence of SARI, like human coronaviruses, bocaviruses, and others [64-66]. The subset of children with SARI who were swabbed were more likely to have several indicators of more severe illness (like chest indrawing) than children with SARI who were not swabbed, although low oxygen saturation was more often observed in children who were not swabbed. Thus, incidence rates of pathogens which are linked to specific clinical presentations may have been overestimated. For calculating pathogenspecific incidence rates of SARI, we used one adjustment factor, based on the proportion of all clinic visits for SARI that were to the study clinic, because there was no available approach to make this adjustment by etiology; however, in reality, study clinic visitation patterns may not have been consistent across etiologies, since some may be associated with symptoms more likely to induce a visit to the study clinic, rather than other clinics in the area. Finally, since our case definitions for SARI did not include apnea, which can be a severe manifestation of RSV-associated bronchiolitis in neonates, we likely underestimated the role of RSV in young infants. Furthermore, the active case detection, and enhancements within the community to encourage early treatment, may have reduced mortality from SARI, and also reduced detection of more severe forms of the syndrome, probably led to underestimations of incidence, especially for pathogens most likely to result in greater clinical severity of illness; thus, our findings may not be representative of SARI cases studied elsewhere.

\section{Conclusions}

The findings from this study suggest that interventions focused on preventing influenza A, RSV, and, perhaps a combination of parainfluenza viruses, adenovirus and human metapneumoviruses may have substantial impact on further reducing the burden of respiratory infections in children in developing countries, adding to the expected impact of pneumococcal conjugate vaccines, which are in the process of being introduced in lower income countries in Africa and Asia, and expected to diminish pneumococcal disease burden [67]. For influenza, a variety of tools (vaccines and strategies to deliver them) already exist $[68,69]$. For several other key viral pathogens, vaccine development continues to progress [70,71]. Non-etiology-specific interventions like improving hand hygiene, reducing exposure to smoke in the home [72,73], and making oxygen available in clinical settings will likely contribute to reducing severe illness and mortality.

\section{Competing interests}

The authors declare that they have no competing interests.

\section{Authors' contributions}

RFB, MKN and DRF conceived the overall study and focused on its design and coordination. LC and JW designed the basic and complex statistical analyses to achieve study objectives. RFB, MAK, DDE, ES, MSO, and DRF designed the sub-study to evaluate additional respiratory pathogens. MKN, $\mathrm{DDE}, \mathrm{MSO}, \mathrm{NW}$, and BSF contributed to the diagnostic component of the study. RFB, LC, MKN, HN, DMO, KO, GOO, BO, NW, and DRF designed the details of the field work, including data and specimen collection, and 
linkage of laboratory results with epidemiologic data. RFB drafted the initial manuscript and all co-authors participated in additional shaping and finalizing it. All authors read and approved the final manuscript.

\section{Acknowledgements}

The authors would like to thank the people living in the Gatwikera and Soweto villages of Kibera and the community leaders, who, over the years, have graciously allowed our field teams to enter their homes on a regular basis to collect information on their health. This study was funded by the US Centers for Disease Control and Prevention (CDC), which contributed to study design, collection, analysis and interpretation of data, as well as the writing of the manuscript, since several of the authors are employees of CDC. The authors would also like to thank the Kenya Medical Research Institute (KEMRI), its leadership and staff; without the collaboration between KEMRI and CDC, this work would not have been possible.

\section{Author details}

${ }^{1}$ Global Disease Detection Division and Influenza Division of the United States Centers for Disease Control and Prevention (CDC Kenya office), Nairobi, Kenya. ${ }^{2}$ Global Disease Detection Branch, Division of Global Health Protection, Center for Global Health, Centers for Disease Control and Prevention, Atlanta, GA, USA. ${ }^{3}$ Division of Viral Diseases, National Center for Immunizations and Respiratory Diseases, Centers for Disease Control and Prevention, Atlanta, GA, USA. ${ }^{4}$ The Kenya Medical Research Institute (KEMRI), Nairobi, Kenya. ${ }^{5}$ Current address: Emory Global Health Institute, Emory University, 1599 Clifton Road, Atlanta, GA 30322, USA.

\section{Received: 7 August 2014 Accepted: 11 February 2015} Published online: 25 February 2015

\section{References}

1. Black RE, Cousens S, Johnson HL, Lawn JE, Rudan I, Bassani DG, et al. Child Health Epidemiology Reference Group of WHO and UNICEF. Global, regional, and national causes of child mortality in 2008: a systematic analysis. Lancet. 2010;375:1969-87.

2. Greenwood BM, Weber MW, Mulholland K. Childhood pneumoniapreventing the world's biggest killer of children. Bull World Health Organ. 2007;85(7):502-3.

3. Rudan I, Boschi-Pinto C, Biloglav Z, Mulholland K, Campbell H. Epidemiology and etiology of childhood pneumonia. Bull World Health Organ. 2008;86(5):408-16.

4. Nair H, Simões EA, Rudan I, Gessner BD, Azziz-Baumgartner E, Zhang JS, et al. Global and regional burden of hospital admissions for severe acute lower respiratory infections in young children in 2010: a systematic analysis. Lancet. 2013. doi:pii: S0140-6736(12)61901-1.

5. Rudan I, El Arifeen S, Bhutta ZA, Black RE, Brooks A, Chan KY, et al. WHO/CHNRI Expert Group on Childhood Pneumonia. Setting research priorities to reduce global mortality from childhood pneumonia by 2015. PLoS Med. 2011;8(9):e1001099.

6. Berman S. Acute respiratory infections. Infect Dis Clin North Am. 1991;5 (2):319-36.

7. Denny FW, Loda FA. Acute respiratory infections are the leading cause of death in children in developing countries. Am J Trop Med Hyg. 1986;35:1-2.

8. Liu L, Johnson HL, Cousens S, Perin J, Scott S, Lawn JE, et al. Child Health Epidemiology Reference Group of WHO and UNICEF. Global, regional, and national causes of child mortality: an updated systematic analysis for 2010 with time trends since 2000. Lancet. 2012;379:2151-61.

9. Lozano R, Naghavi M, Foreman K, Lim S, Shibuya K, Aboyans V, et al. Global and regional mortality from 235 causes of death for 20 age groups in 1990 and 2010: a systematic analysis for the Global Burden of Disease Study 2010. Lancet. 2013;380:2095-128.

10. Shann F. Etiology of severe pneumonia in children in developing countries. Pediatr Infect Dis. 1986:5:247-52.

11. Selwyn BJ. The epidemiology of acute respiratory tract infection in young children: comparison of findings from several developing countries. Coordinated Data Group of BOSTID Researchers. Rev Infect Dis. 1990;12 Suppl 8:S870-88

12. Scott JA, Brooks WA, Peiris JS, Holtzman D, Mulholland EK. Pneumonia research to reduce childhood mortality in the developing world. J Clin Invest. 2008;118:1291-300.

13. Levine OS, O'Brien KL, Deloria-Knoll M, Murdoch DR, Feikin DR, DeLuca AN, et al. The pneumonia etiology research for child health project: a 21st century childhood pneumonia etiology study. Clin Infect Dis. 2012;54 Suppl 2:S93-\$101.

14. Ruuskanen O, Lahti E, Jennings LC, Murdoch DR. Viral pneumonia. Lancet. 2011;377:1264-75.

15. Murdoch DR, O'Brien $\mathrm{KL}$, Scott JA, Karron RA, Bhat N, Driscoll AJ, et al. Breathing new life into pneumonia diagnostics. J Clin Microbiol. 2009;47:3405-8.

16. United Nations Human Settlements Programme (UN-HABITAT). The state of African cities: governance, inequalities and urban land markets. Nairobi: United Nations Human Settlements Programme; 2010. p. 270.

17. Kim CY, Breiman RF, Cosmas L, Audi A, Aura B, Bigogo G, et al. Secondary Household Transmission of 2009 Pandemic Influenza A (H1N1) Virus among an Urban and Rural Population in Kenya, 2009-2010. PLoS One. 2012;7(6): e38166. Epub 2012 Jun 11

18. Burton DC, Flannery B, Onyango B, Larson C, Alaii J, Zhang X, et al. Healthcare-seeking behaviour for common infectious disease-related illnesses in rural Kenya: a community-based house-to-house survey. J Health Popul Nutr. 2011;29(1):61-70.

19. Breiman RF, Olack B, Shultz A, Roder S, Kimani K, Feikin DR, et al. Healthcare-use for major infectious disease syndromes in an informal settlement in Nairobi, Kenya. J Health Popul Nutr. 2011;29(2):123-33.

20. Feikin DR, Njenga MK, Bigogo G, Aura B, Aol G, Audi A, et al. Viral and bacterial causes of severe acute respiratory illness among children less than 5 years old in a high malaria prevalence area of Western Kenya, 2007-2010. Pediatr Infect Dis J. 2012. [Epub ahead of print].

21. Feikin DR, Olack B, Bigogo GM, Audi A, Cosmas L, Aura B, et al. The burden of common infectious disease syndromes at the clinic and household level from population-based surveillance in rural and urban Kenya. PLoS One. 2011;6(1):e16085. Jan 18.

22. Njuguna HN, Cosmas L, Williamson J, Nyachieo D, Olack B, Ochieng JB, et al. Use of population-based surveillance to define the high incidence of Shigellosis in an urban slum in Nairobi, Kenya. PLoS One. 2013;8(3): e58437. doi:10.1371/journal.pone.0058437. Epub 2013 Mar 7.

23. Olack B, Feikin DR, Cosmas LO, Odero KO, Okoth GO, Montgomery JM, et al. Mortality trends observed in population-based surveillance of an urban slum settlement, Kibera, Kenya, 2007-2010. PLoS One. 2014;9(1):e85913. doi:10.1371/journal.pone.0085913.

24. Dalal W, Feikin DR, Amolloh M, Ransom R, Burke H, Lugalia F, et al. Homebased HIV Testing and Counseling in rural and urban Kenyan communities. J Acquir Immune Defic Syndr. 2012 Oct 15. [Epub ahead of print].

25. Integrated Management of Childhood IIIness. World Health Organization; 2008. http://whqlibdoc.who.int/publications/2008/9789241597289_eng.pdf Accessed January 28, 2009.

26. McNarry AF, Goldhill DR. Simple bedside assessment of level of consciousness: comparison of two simple assessment scales with the Glasgow Coma scale. Anaesthesia. 2004;59(1):34-7.

27. Waiboci LW, Lebo E, Williamson JM, Mwiti W, Kikwai GK, Njuguna H, et al. Viral shedding in patients infected with pandemic influenza $A(H 1 N 1)$ virus in Kenya, 2009. PLos One. 2011;6 Epub June 2011.

28. CLSI. Performance Standards for Antimicrobial Susceptibility Testing; Nineteenth Informational Supplement. CLSI document M100-S19. Wayne, PA: Clinical and Laboratory Standards Institute; 2009. p. M100-S118.

29. WHO collaborating Centre for Influenza. CDC protocol of real-time RTPCR for influenza A (H1N1). 2009; http://dse.healthrepository.org/bitstream/123456789/ 154/1/CDCrealtimeRTPCRprotocol_20090428.pdf. Accessed March 30, 2012.

30. Kodani M, Yang G, Conklin LM, Travis TC, Whitney CG, Anderson LJ, et al. Application of TaqMan low-density arrays for simultaneous detection of multiple respiratory pathogens. J Clin Microbiol. 2011;49:2175-82.

31. CDC. Clusters of acute respiratory illness associated with human enterovirus 68 - Asia, Europe, and United States, 2008-2010. MMWR Morb Mortal Wkly Rep. 2011;60:1301-4.

32. Lu X, Holloway B, Dare RK, Kuypers J, Yagi S, Williams JV, et al. Real-time reverse transcription-PCR assay for comprehensive detection of human rhinoviruses. J Clin Microbiol. 2008:46:533-9.

33. Nix WA, Maher $K$, Johansson ES, Niklasson B, Lindberg AM, Pallansch MA et al. Detection of all known parechoviruses by real-time PCR. J Clin Microbiol. 2008;46:2519-24.

34. Gikunju S, Schneider E, Feikin D, Mailu E, Ochieng M, Whitaker B, et al. Rhinovirus/Enterovirus Detections in Respiratory Specimens from Persons with Severe Acute Respiratory Illness in Rural and Urban, Kenya, 2009. Rome Italy: XIII International Symposium on Respiratory Viral Infections; 2011. 
35. Thurman KA, Warner AK, Cowart KC, Benitez AJ, Winchell JM. Detection of Mycoplasma pneumoniae, Chlamydia pneumoniae, and Legionella spp. in clinical specimens using a single-tube multiplex real-time PCR assay. Diagn Microbiol Infect Dis. 2011;70:1-9.

36. Bickel PJ. Mathematical Statistics: Basic Ideas and Selected Topics. Upper Saddle River, New Jersey: Prentice Hall, Inc; 2001.

37. Kleinbaum DG, Kupper LL, Morganstern H. Epidemiologic Research. New York: Van Nostrand Reinhold; 1982.

38. Singleton RJ, Bulkow LR, Miernyk K, DeByle C, Pruitt L, Hummel KB, et al. Viral respiratory infections in hospitalized and community control children in Alaska. J Med Virol. 2010;82:1282-90.

39. Breiman RF, Cosmas L, Njuguna H, Audi A, Olack B, Ochieng JB, et al. Population-Based Incidence of Typhoid Fever in an Urban Informal Settlement and a Rural Area in Kenya: Implications for Typhoid Vaccine Use in Africa. PLoS ONE. 2012;7(1):e29119. doi:10.1371/journal.pone.0029119.

40. Miettinen OS. Proportion of disease caused or prevented by a given exposure, trait or intervention. Am J Epidemiol. 1974;99:325-32.

41. Blackwelder WC, Biswas K, Wu Y, Kotloff KL, Farag TH, Nasrin D, et al. Statistical methods in the Global Enteric Multicenter Study (GEMS). Clin Infect Dis. 2012;55 Suppl 4:S246-53.

42. Thompson MG, Breiman RF, Hamel MJ, Desai M, Emukule G, Khagayi S, et al Influenza and malaria coinfection among young children in western Kenya, 2009-2011. J Infect Dis. 2012;206(11):1674-84. Dec 1.

43. Weber MW, Mulholland EK, Greenwood BM. Respiratory syncytial virus infection in tropical and developing countries. Trop Med Int Health. 1998;3:268-80

44. Nair H, Nokes DJ, Gessner BD, Dherani M, Madhi SA, Singleton RJ, et al. Global burden of acute lower respiratory infections due to respiratory syncytial virus in young children: a systematic review and meta-analysis. Lancet. 2010:375:1545-55.

45. Katz MA, Schoub BD, Heraud JM, Breiman RF, Njenga MK, Widdowson MA. Influenza in Africa: uncovering the epidemiology of a long-overlooked disease. J Infect Dis. 2012;206 Suppl 1:S1-4. doi:10.1093/infdis/jis548.

46. Radin JM, Katz MA, Tempia S, Talla Nzussouo N, Davis R, Duque J, et al. Influenza surveillance in 15 countries in Africa, 2006-2010. J Infect Dis. 2012;206 Suppl 1:S14-21. Dec 15.

47. Nair H, Brooks WA, Katz M, Roca A, Berkley JA, Madhi SA, et al. Global burden of respiratory infections due to seasonal influenza in young children: a systematic review and meta-analysis. Lancet. 2011;378:1917-30.

48. Viboud C, Alonso WJ, Simonsen L. Influenza in tropical regions. PLoS Med. 2006;3(4):e89. doi:10.1371/journal.pmed.0030089.

49. Hai LT, Bich VTN, Ngai LK, Diep NTN, Phuc PH, Hung VP, et al. Fatal respiratory infections associated with rhinovirus outbreak, Vietnam. Emerg Infect Dis. 2012;18:1886-8 [Internet].

50. Briese T, Renwick N, Venter M, Jarman RG, Ghosh D, Kondgen S. Global distribution of novel rhinovirus genotype. Emerg Infect Dis. 2008;14:944-7.

51. Lee WM, Kiesner C, Pappas T, Lee I, Grindle K, Jartti T. A diverse group of previously unrecognized human rhinoviruses are common causes of respiratory illnesses in infants. PLoS One. 2007;2:e966.

52. Hoffmann J, Rabezanahary H, Randriamarotia M, Ratsimbasoa A, Najjar J, Vernet $\mathrm{G}$, et al. Viral and atypical bacterial etiology of acute respiratory infections in children under 5 years old living in a rural tropical area of Madagascar. PLoS One. 2012;7(8):e43666. doi:10.1371.

53. Touati A, Pereyre S, Bouziri A, Achour W, Khaldi A, Ben Jaballah N, et al. Prevalence of Mycoplasma pneumoniae-associated respiratory tract infections in hospitalized children: results of a 4-year prospective study in Tunis. Diagn Microbiol Infect Dis. 2010:68:103-9.

54. Garnett CT, Erdman D, Xu W, Gooding LR. Prevalence and quantitation of species $C$ adenovirus DNA in human mucosal lymphocytes. J Virol. 2002;76(21):10608-16

55. Hammitt LL, Kazungu S, Morpeth SC, Gibson DG, Mvera B, Brent AJ, et al. A preliminary study of pneumonia etiology among hospitalized children in Kenya. Clin Infect Dis. 2012;54 Suppl 2:S190-9.

56. O'Brien KL, Wolfson $\amalg$, Watt JP, Henkle E, Deloria-Knoll M, McCall N, et al, Burden of disease caused by Streptococcus pneumoniae in children younger than 5 years: global estimates. Lancet. 2009;374:893-902.

57. Tabu C, Breiman RF, Ochieng B, Aura B, Cosmas L, Audi A, et al. Differing burden and epidemiology of non-Typhi Salmonella bacteremia in rural and urban Kenya, 2006-2009. PloS One. 2012;7(2):e31237. Epub 2012 Feb 21.

58. Madhi SA, Petersen K, Madhi A, Khoosal M, Klugman KP. Increased disease burden and antibiotic resistance of bacteria causing severe community-acquired lower respiratory tract infections in human immunodeficiency virus type 1-infected children. Clin Infect Dis. 2000;31:170-6.

59. Johnson AW, Osinusi K, Aderele WI, Gbadero DA, Olaleye OD, Adeyemi-Doro FA. Etiologic agents and outcome determinants of community-acquired pneumonia in urban children: a hospital-based study. J Natl Med Assoc. 2008;100:370-85.

60. Cutts FT, Zaman SM, Enwere G, Jaffar S, Levine OS, Okoko JB, et al. Gambian Pneumococcal Vaccine Trial Group. Efficacy of nine-valent pneumococcal conjugate vaccine against pneumonia and invasive pneumococcal disease in The Gambia: randomised, double-blind, placebo-controlled trial. Lancet. 2005;365:1139-46.

61. Sung RY, Chan PK, Choi KC, Yeung AC, Li AM, Tang JW, et al. Comparative study of nasopharyngeal aspirate and nasal swab specimens for diagnosis of acute viral respiratory infection. J Clin Microbiol. 2008;46:3073-6.

62. Martin ET, Kuypers J, Heugel J, Englund JA. Clinical disease and viral load in children infected with respiratory syncytial virus or human metapneumovirus. Diagn Microbiol Infect Dis. 2008;62:382-8.

63. El Saleeby CM, Bush AJ, Harrison LM, Aitken JA, Devincenzo JP. Respiratory syncytial virus load, viral dynamics, and disease severity in previously healthy naturally infected children. J Infect Dis. 2011;204:996-1002.

64. Anderson LJ, Baric RS. Emerging human coronaviruses-disease potential and preparedness. N Engl J Med. 2012;367:1850-2.

65. Debiaggi M, Canducci F, Ceresola ER, Clementi M. The role of infections and coinfections with newly identified and emerging respiratory viruses in children. Virol J. 2012:9:247.

66. Raoult D, La Scola B, Birtles R. The discovery and characterization of Mimivirus, the largest known virus and putative pneumonia agent. Clin Infect Dis. 2007:45:95-102.

67. Ayieko P, Griffiths UK, Ndiritu M, Moisi J, Mugoya IK, Kamau T, et al. Assessment of health benefits and cost-effectiveness of 10-valent and 13-valent pneumococcal conjugate vaccination in Kenyan children. PLoS One. 2013;8:e67324. doi:10.1371.

68. World Health Organization. Influenza Vaccines: Position Paper. Weekly Epidemiol Rec. 2005;33:279-87.

69. World Health Organization. Meeting of the Strategic Advisory Group of Experts on immunization, April 2012-conclusions and recommendations. Weekly Epidemiol Rec. 2012;21:201-16.

70. Anderson LJ, Dormitzer PR, Nokes DJ, Rappuoli R, Roca A, Graham BS. Strategic priorities for RSV vaccine development. Vaccine. 2013;31(Supp 2):B209-15.

71. Chen Z, Xu P, Salyards GW, Harvey SB, Rada B, Fu ZF, et al. Evaluating a parainfluenza virus 5-based vaccine in a host with pre-existing immunity against parainfluenza virus 5. PLoS One. 2012;7(11):e50144. doi:10.1371/journal. pone.0050144. Epub 2012 Nov 20.

72. Luby SP, Agboatwalla M, Feikin DR, Painter J, Billhimer W, Altaf A, et al. Effect of handwashing on child health: a randomised controlled trial. Lancet. 2005;366:225-33

73. Smith KR, McCracken JP, Weber MW, Hubbard A, Jenny A, Thompson LM, et al. Effect of reduction in household air pollution on childhood pneumonia in Guatemala (RESPIRE): a randomised controlled trial. Lancet. 2011;378:1717-26

\section{Submit your next manuscript to BioMed Central and take full advantage of:}

- Convenient online submission

- Thorough peer review

- No space constraints or color figure charges

- Immediate publication on acceptance

- Inclusion in PubMed, CAS, Scopus and Google Scholar

- Research which is freely available for redistribution 